\title{
PEMBERDAYAAN PENGRAJIN PRODUK APEM DI DESA KADUBUNGBANG-CIMANUK-PANDEGLANG
}

\author{
*Akhmad Nidhomuz Zaman ${ }^{1}$, Santika Sari ${ }^{2}$, Fitri Wahyuni ${ }^{3}$, Noverdo Saputra ${ }^{4}$ \\ 1, 2, 3,4 Fakultas Teknik, Universitas Pembangunan Nasional Veteran Jakarta \\ Email : santika.sari@upnvj.ac.id
}

\begin{abstract}
The development of the industrial center area is one of the efforts to build a local economy that aims to construct commodity-based production of the village that is owned by the local community. Community Service (PKM) is carried out in Kadubungbang-Pandeglang Village. PKM is done to assist in the empowerment of typical Pandeglang culinary business in the home industry "Apem Bohay Barokah". The current problem is not yet maximized in apem marketing (in terms of packaging and sales that are still sold around the village). Marketing is assisted on the packaging side with contemporary packaging designs and making posters to be better known and known to the general public. PKM was accepted by Apem Bohay Pandeglang's business. Marketing is not only done in terms of packaging products and banners but also assisted in terms of digitizing one of them with the android application. It is hoped that this empowerment can be better known by the Pandeglang community as well as expanding and establishing sustainable partnerships.
\end{abstract}

Keywords: home industry, culinary, marketing, empowerment.

\begin{abstract}
ABSTRAK
Pembangunan kawasan sentra industri merupakan salah satu upaya untuk membangun perekonomian lokal yang bertujuan membangun produksi berbasis komoditas unggulan Desa yang dimiliki oleh masyarakat setempat. Pelaksanaan kegiatan Pengabdian Kepada Masyarakat (PKM) dilakukan di Desa Kadubungbang-Pandeglang. PKM yang dilakukan adalah membantu dalam pemberdayaan usaha kuliner khas pandeglang pada home industri "Apem Bohay Barokah". Permasalahan saat ini adalah belum maksimal pada pemasaran apem (dari sisi pengemasan dan penjualan yang masih di jual disekitar Desa). Pemasaran di bantu pada sisi pengemasan dengan desain pengemasan yang kekinian serta membuat poster untuk lebih dikenal dan diketahui khalayak umum. PKM diterima pihak usaha Apem Bohay Pandeglang. Pemasaran tidak hanya dilakukan dari sisi pengemasan produk dan spanduk tetapi juga dibantu dari sisi digitalisasi salah satunya dengan aplikasi android. Diharapkan pemberdayaan ini bisa lebih di kenal masyarakat Pandeglang serta meluas dan terjalin kemitraan yang bekelanjutan.
\end{abstract}

Kata kunci: home industri, kuliner, pemasaran, pemberdayaan 


\section{PENDAHULUAN}

Salah satu bentuk usaha dan upaya dalam mengembangkan perekonomian warga Desa adalah melalui pengolahan potensi alam yang dimiliki oleh masyarakat sekitar sebagai bahan baku menjadi barang jadi melalui kegiatan industri. Pembangunan kawasan sentra industri merupakan salah satu upaya untuk membangun perekonomian lokal yang bertujuan membangun produksi berbasis komoditas unggulan Desa yang dimiliki oleh masyarakat setempat melalui kerjasama antara pemerintah, swasta, dan pendidikan tinggi (Endriastuti and Permatasari, 2018).

Tantangan dan hambatan pada era sekarang ini yang dihadapi dalam dunia usaha adalah semakin besar dan semakin ketatnya persaingan. Salah satunya kegiatan yang pesat perkembangannya adalah kegiatan dagang khususnya dalam bidang usaha makanan atau kuliner. Persaingan terjadi semakin ketat hal ini ditandai dengan banyaknya usaha dagang yang menerapkan berbagai strategi yang unik untuk mempertahankan kelangsungan usahanya (Winangsih, 2018).

Salah satu tempat pariwisata di daerah Pandeglang Banten yang akan menjadi lokasi kegiatan Pengabdian Kepada Masyarakat (PKM) berada di Desa Kadubungbang, Kecamatan Cimanuk - Pandeglang. Desa Kadubungbang berada di daerah Pegunungan Pulosari yang terbentang dari barat sampai bagian selatan (Viacenza, 2019). UKM yang berkembang dan menghasilkan produk ciri khas Desa Kadubungbang salah satunya adalah kuliner. Beberapa hasil pertanian Desa digunakan sebagai bahan baku dalam industri kuliner. Industri kuliner salah satu yang menjadi andalan adalah makanan yang disebut “Apem”. Menurut pihak staf kantor Desa Kadubungbang, Apem merupakan makanan khas yang menjadi daya tarik serta oleh-oleh dari Desa yang sering disuguhkan pada acara-acara atau kegiatan tertentu (gambar 1). Resep pada pembuatan Apem merupakan resep turun menurun yang asli dari Desa Kadungbungbang. Secara umum permasalahan pada saat ini adalah belum maksimal pada pemasaran industri kuliner khas yaitu apem (dari sisi pengemasan dan penjualan yang masih di jual disekitar Desa). 

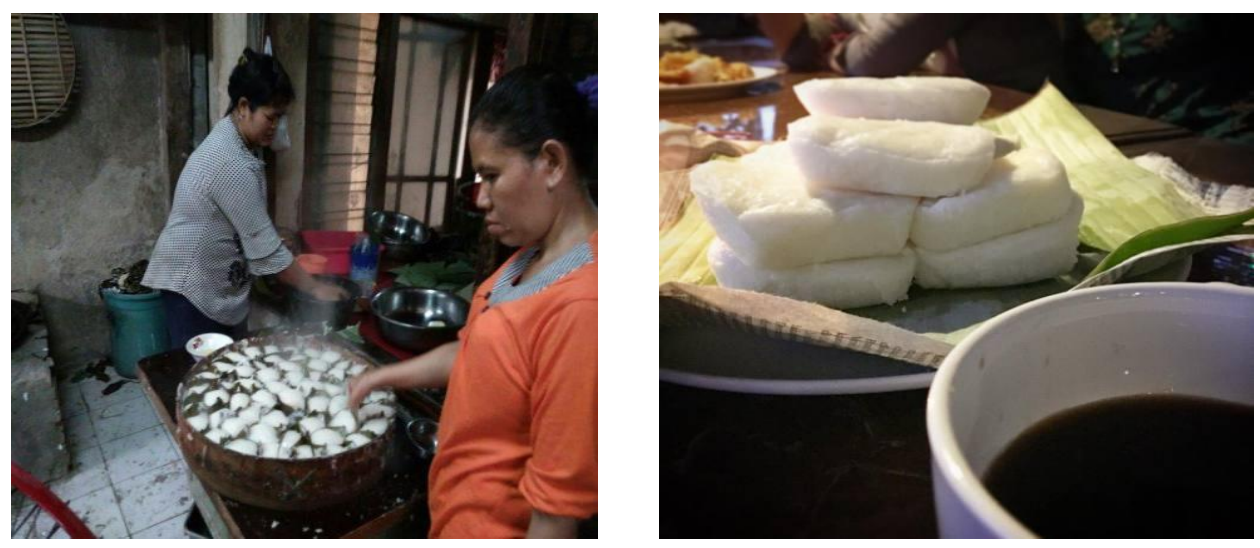

Gambar 1. Kuliner khas Desa Kadubungbang “Apem”

Pada tim PKM dengan nama "Abdi Desa" membantu dalam pemberdayaan usaha kuliner apem pada home industri “Apem Bohay Barokah" salah satu usaha apem di Desa kadubungbang yang berdiri dari tahun sekitar 1970 turun menurun dengan hampir ke-3 generasi. PKM 2020 dilakukan dari referensi yang pernah dilakukan oleh (Andini and Anggraeni, 2016) tentang inovasi kemasan sebagai daya tarik produk dan (Endriastuti and Permatasari, 2018) tentang pemberdayaan toko online. Pemasaran di bantu pada sisi pengemasan dengan desain pengemasan yang kekinian serta membuat poster untuk lebih dikenal dan diketahui khalayak umum. Diharapkan pemberdayaan ini bisa mengenalkan dan lebih di kenal masyarakat Pandeglang serta meluas di luar Pandeglang serta terjalin kemitraan yang bekelanjutan. 


\section{METODE PELAKSANAAN}

Metode pelaksanaan dilakukan 2 tahap, tahap 1 studi pengamatan dan tahap 2 pelaksaan kegiatan sosialisasi. Berikut diagram alir PKM gambar 2:

Mulai

\section{Studi Pengamatan:}

- Informasi tentang kondisi dan keandalan Apem

- Dimensi, jenis, dan bentuk Apem

- Permintaan Dasar tema benner

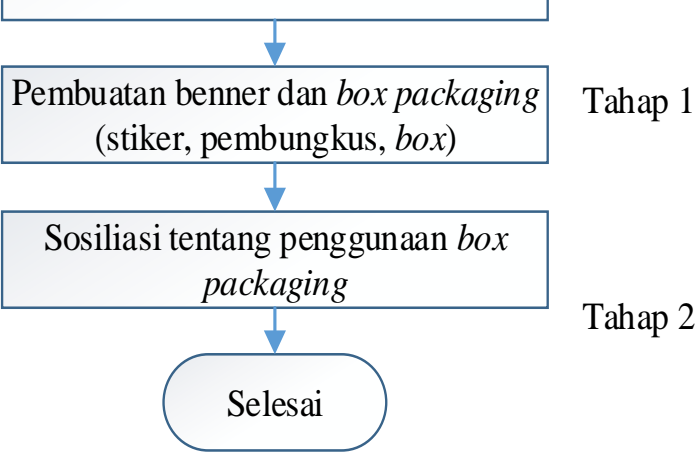

Gambar 2. Diagram Alir PKM

\section{Tahap 1}

Sebelum memulai tahap 1, studi pengamatan dilakukan untuk mengetahui informasi dalam melakukan perancangan ukuran dimensi box, ukuran stiker serta tema yang dapat digunakan menjadi branding dari Produk Apem Bohay Barokah. Desain spanduk dan stiker dibuat berdasarkan komunikasi dua arah antara tim design PKM dan pihak pemilik usaha. Desain PKM juga disesuaikan dengan hasil riset marketing mengenai info apasaja yang harus diberikan dalam kemasan produk. Selain itu desain tersebut juga menonjolkan bahwa produk merupakan makanan khas daerah Cimanuk-Pandeglang, Banten.

\section{Tahap 2}

Setelah desain spanduk, stiker, dan box selesai sudah ada persetujuan dari pihak usaha maka akan dilakukan sosialisasi langsung pada pihak usaha dengan didampingi 3 Dosen dan 4 mahasiswa. 


\section{HASIL DAN PEMBAHASAN}

Pada Pelaksanaan PKM terdapat beberapa tahap, secara umum terdiri dari 2 tahap pelaksanaan, yaitu:

Tabel 1. Kegiatan Tim PKM

\begin{tabular}{|c|c|c|c|c|}
\hline No & Kegiatan & Sesi & Waktu & PIC \\
\hline 1 & $\begin{array}{l}\text { Studi Pengamatan dan } \\
\text { Pembuatan } \\
\text { spanduk, stiker, } \\
\text { serta pemesanan } \\
\text { box }\end{array}$ & & Juni 2020 & $\begin{array}{r}3 \text { Dosen dan } 4 \\
\text { mahasiswa }\end{array}$ \\
\hline 2 & $\begin{array}{l}\text { Sosialisasi: } \\
\text { a. Penggunaan box } \\
\text { dan dimensinya, } \\
\text { pemesangan } \\
\text { benner Apem } \\
\text { Bohay } \\
\text { b. Penyuluhan cara } \\
\text { memaksimalkan } \\
\text { marketing dengan } \\
\text { adanya pendukung } \\
\text { seperti spanduk } \\
\text { dan stiker dalam } \\
\text { packaging }\end{array}$ & $\begin{array}{l}11.00 \\
\text { WIB - } \\
\text { selesai }\end{array}$ & Juli 2020 & $\begin{array}{r}3 \text { Dosen dan } 4 \\
\text { mahasiswa }\end{array}$ \\
\hline
\end{tabular}

Berikut penjelasan mengenai studi pengamatan, pembuatan Tabel 1 adalah tentang kegiatanTim PKM pada unit produksi rumahan “Apem Bohay Barokah" $\mathrm{Hj} \mathrm{Ucah}$, Desa Kadubumbang, berikut penjelasanya:

1. Studi Pengamatan dan pembuatan, hasil yang didapat adalah: Harga 1 Produk isi 10 Buah $=$ Rp. 15.000, Produk ini biasanya di jual dalam keadaan hangat atau panas namun bisa juga dalam keadaan dingin, jika dibungkus dengan daun pisang dapat bertahan sampai 2-3 hari di suhu ruangan, Jika dimasukkan di lemari es bisa lebih 3 hari, namun menjadi keras dan harus dihangatkan terlebih dahulu. Satu hari bisa memproduksi 3000 pesanan. Semua hasil informasi tersebut didapatkan dari survey pengamatana awal dan koordinasi online via zoom. Dari hasil pengamatan tersebut tim PKM melakukan disain dengan membuat 1 box berisi 18-20 apem yang diberikan stiker pada penutup box (gambar 3). Stiker tersebut memuat informasi yang diperlukan untuk memberikan branding kepada pembeli sekaligus sebagai sarana marketing produk "Apem" khas 
Cimanuk. Pada Gambar 4 merupakan hasil akhir box yag telah diberikan stiker yang memuat informasi terkait nama produk, komposisi bahan, alamat, gambar, expired date, dan nomor telepon untuk memesan. Selain memberikan rancangan pengemasan untuk pembelian dalam jumlah besar, Tim PKM juga memberikan alternatif rancangan jika terdapat pembelian dalam jumlah kecil antara 8-10 Apem. Dapat dilihat pada gambar 5 merupakan hasil disain packaging untuk pembelian apem dalam jumlah kecil yang berupa kertas pembungkus yang telah dicetak dengan memberikan informasiinformasi penting yang diperlukan untuk sarana marketing dan branding produk yang lebih ekonomis. Kertas yang telah dicetak dengan disain pada gambar 5 tersebut selanjutnya dilapisi oleh daun pisang dan diisi oleh Apem dengan jumlah lebih sedikit daripada dalam box. Selain memberikan disain yang berfungsi untuk pengemasan, tim PKM juga melakukan rancangan disain spanduk untuk membantu unit usaha "Apem Bohay Barokah" agar dapat lebih dikenal oleh wisatawan yang berkunjung. Pada Gambar 6 merupakan disain spanduk yang dicetak dengan ukuran 1,5m x 3m guna membantu mempromosikan produk “Apem Bohay Barokah" sebagai makanan khas Cimanuk.

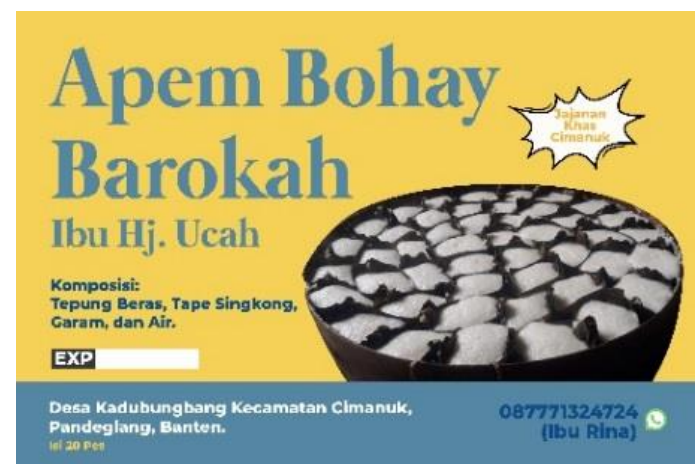

Gambar 3. Hasil Disain untuk Stiker Pada Box Plastik
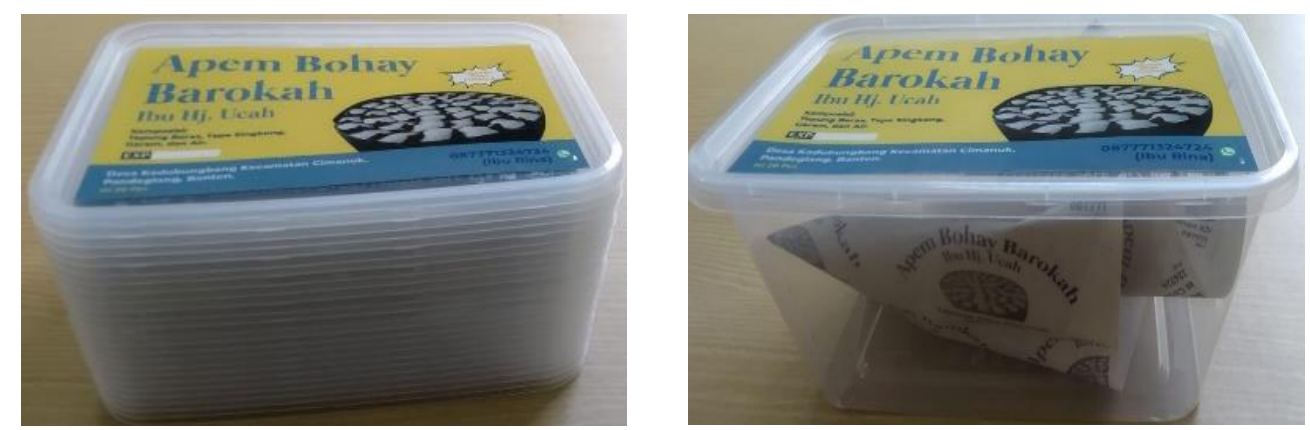

Gambar 4. Hasil Box Plastik yang telah diberikan Stiker untuk Branding Produk 


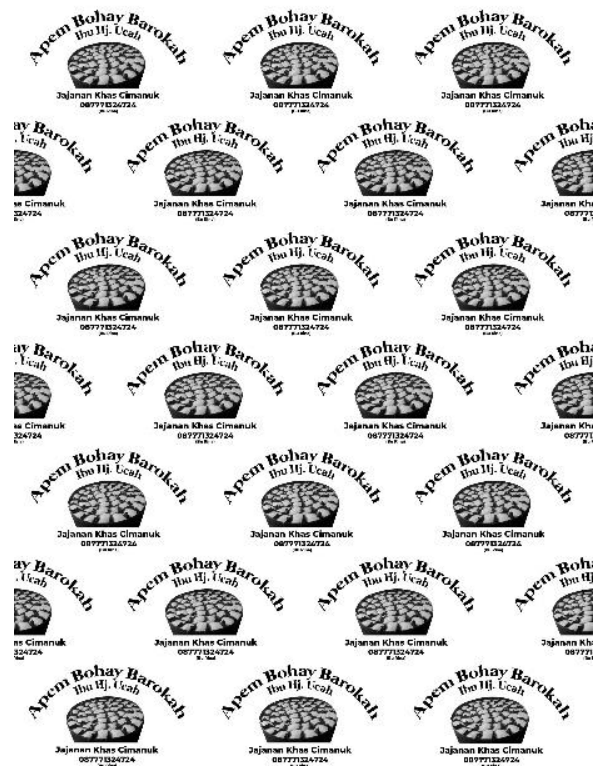

Gambar 5. Hasil Disain Packaging untuk Pembelian Apem dalam Jumlah Kecil.

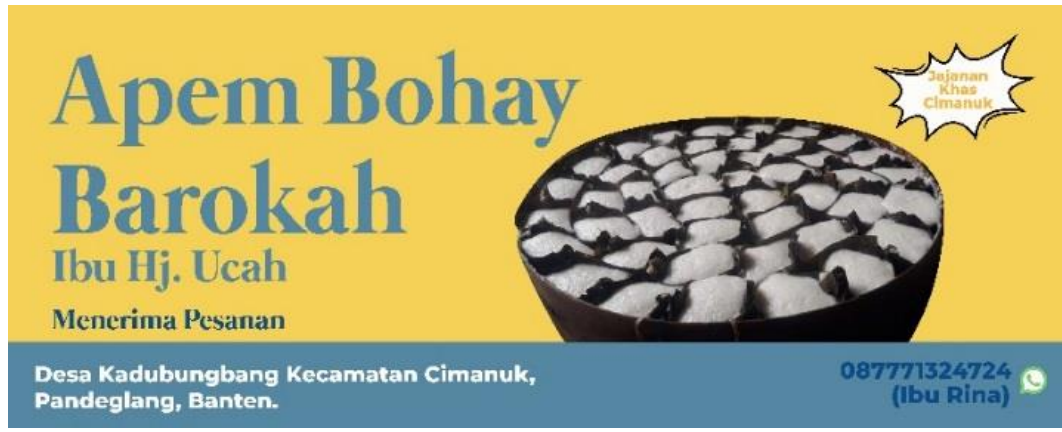

Gambar 6. Hasil Disain Spanduk

2. Hasil dari studi pengamatan langsung saat pelaksanaan pengabdian masyarakat. Apem Bohay sebenarnya sudah dikatan usaha yang bisa bertahan namun disatu sisi dengan perkembangan teknologi, perlu dilakukan pemasaran yang lebih melibatkan teknologi kekinian / digital. Salah satu usaha ini dimasukkan dalam "aplikasi android" yang dikembangkan (As'adi et al., 2020) untuk bisa lebih dikenal warga umum. Dengan itu maka tim PKM melakukan kolaborasi dengan tim yang lain dengan memberikan info mengenai makanan khas Cimanuk yaitu “Apem” kedalam aplikasi android yang dapat dilihat dalam gambar 7.

Disain spanduk, stiker, dan box yang telah disiapkan disosialisasikan kepada pihak usaha Apem Bohay dengan peragaan beberapa contoh Apem dalam box. 


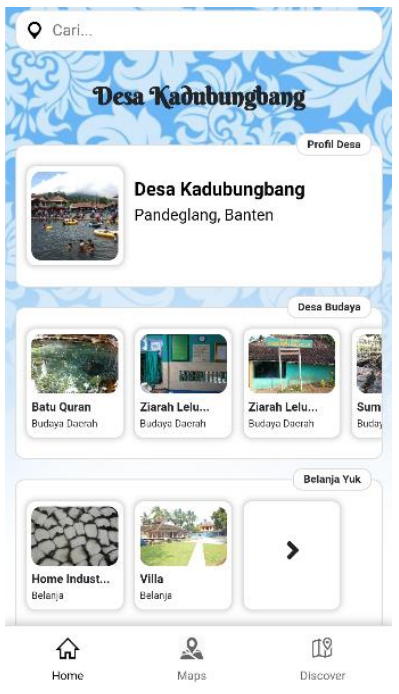

Gambar 7. Informasi tentang Apem Bohay di Aplikasi ’Desa Digital”

Dari semua rangkaian kegiatan PKM yang menjelaskan mengenai pentingnya melakukan pemasaran yang dapat diwujudkan dalam pengemasan dan branding produk, untuk lebih dikenal wisatawan diluar desa Pandeglang maupun penduduk sekitar desa Pandeglang.
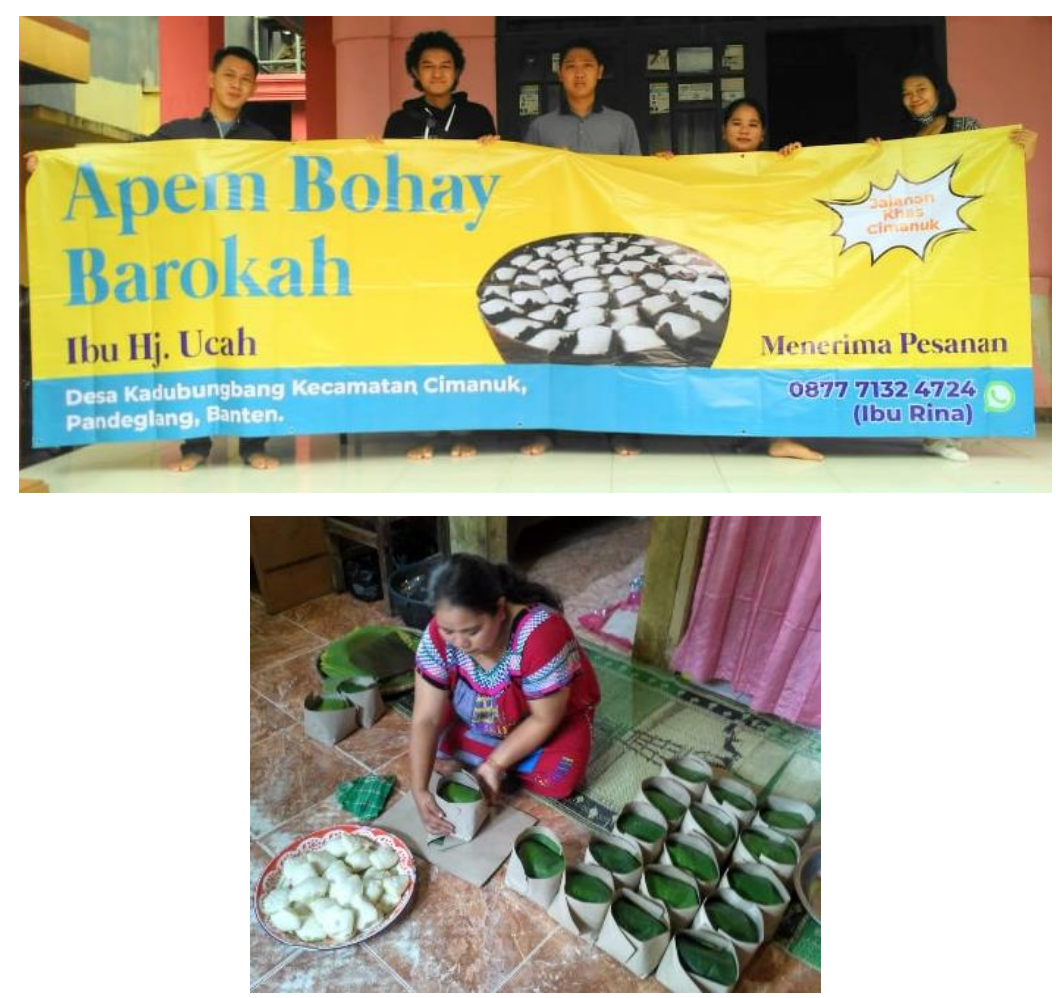

Gambar 8. Kegiatan TIM PKM Abdi Desa 2020

Kesimpulan dari kegiatan PKM ini bahwa dalam unit usaha industri makanan khas daerah dibutuhkan usaha lebih untuk memarketingkan produk makanan khas tersebut. Oleh karena 
itu kami membantu unit usaha industry Apem khas Cimanuk untuk mempromosikan secara lebih makanan khas daerahnya dengan cara membuatkan disain kemasan dan spanduk. Tidak hanya dari segi kemasan produk dan spanduk yang telah diberikan branding bahwa "Apem" adalah makanan khas Cimanuk, namun dari sisi digitalisasi juga diberikan info mengenai "Apem" adalah makanan khas daerah tersebut dalam aplikasi android "Desa Digital".

\section{DAFTAR PUSTAKA}

Andini, D. P. and Anggraeni, O. J. (2016) 'Inovasi Kemasan Sebagai Daya Tarik Produk Aneka Camilan di Desa Curah Malang Kecamatan Rambipuji Kabupaten Jember', (1), pp. 156-158.

As, adi M. Zaman, AN. Viacenza, AN. Dewi, AC. Motreano, D. (2020) 'Jurnal Manajemen Industri dan Logistik Kajian Model Desain Aplikasi Mobile Yang Berkelanjutan Study Of Sustainable Mobile Application Design Models In Tourism Villages', 04(01), pp. 47-57.

Endriastuti, A. and Permatasari, M. P. (2018) 'Pelatihan Pemasaran, Pemberdayaan Toko Online, Dan Pengenalan M-Commerce Pada Produk Unggulan Jagung Tortiladi Kecamatan Trucuk Kabupaten Bojonegoro', Martabe: Jurnal Pengabdian Kepada Masyarakat, 1(2), p. 56. doi: 10.31604/jpm.v1i2.56-66.

Viacenza, a. N. (2019) Pengembangan Industri Pariwisata Berbasis Aplikasi Mobile Dengan Metode System Development Life Cycle Dan Quality Function Deployment. Universitas Pembangunan Nasional 'veteran' Jakarta. Available at: http://repository.upnvj.ac.id/487/.

Winangsih, N. W. W. dan R. (2018) 'Desain Kemasan Kelompok Usaha Produsen Dan Retailer Makanan “Kue Subuh ” Improving Competitiveness Of Micro Business Products Through Food Cake Packaging And Food Business Business Prodi Ilmu Komunikasi Universitas Sultan Ageng Tirtayasa pendahuluan Pada', 4(1), pp. 1725 . 